\title{
Management and Outcomes of Paediatric Patients with Palpitations Examined in Our Clinic
}

\section{Çarpıntı Şikayeti ile Kliniğimizde İncelenen Çocuk Hastaların Sonuçları ve Tedavi Yönetimi}

\author{
(i) Kahraman YAKUT
}

Bezmialem Vakıf University Faculty of Medicine, Department of Pediatric Cardiology, İstanbul, Türkiye

\begin{abstract}
Objective: We retrospectively reviewed the data of patients who presented to the paediatric cardiology clinic with complaints of palpitations. We aimed to describe the characteristics of these patients, the rhythm disorders that were detected, and the treatment methods with a particular attention on rare and vital diseases.

Methods: In total, 1,680 patients aged 5-18 years who presented with palpitations at the paediatric cardiology clinic between January 2016 and June 2019 were enrolled. Of these, 714 (42.5\%) were male and $966(57.5 \%)$ were female. All the hospital records including electrocardiography, echocardiography, cardiovascular stress test, 24-h Holter monitoring, event recorder and genetic analysis results were reviewed.

Results: The mean age of the patients was $13.5 \pm 3.2$ years (range: $5-17.8$ years). Palpitation was accompanied with chest pain in 218 patients, shortness of breath in 152 patients and weakness in 67 patients. Also, 726 Holter monitoring, 165 event recorder and 104 cardiovascular stress test results were evaluated. Dysrhythmia was detected in 306 patients (18.2\%). The most common dysrhythmias were supraventricular extrasystoles $(\mathrm{n}=171,55.8 \%)$ and ventricular extrasystoles $(\mathrm{n}=82,26.8 \%)$. Five patients were diagnosed with non-sustained ventricular tachycardia (VT) episodes, one with long QTc syndrome and one with catecholaminergic polymorphic VT. Two patients were followed-up for arrhythmogenic right ventricular dysplasia (ARVD), 12 patients had mitral valve prolapsed (MVP), 8 had valvular heart disease caused by acute rheumatic fever (ARF) and 7 had bicuspid aortic valve (BAV).
\end{abstract}

\section{ÖZ}

Amaç: $\mathrm{Bu}$ çalışmada, çocuk kardiyoloji polikliniğine çarpıntı şikayeti ile başvuran hastaların bilgileri retrospektif olarak incelendi. $\mathrm{Bu}$ konu ile ilgili güncel yaklaşımlar derlendi, ayrıca seyrek görülen ve hayati önemi olan hastalıklara dikkat çekilmeye çalışıldı.

Yöntemler: Ocak 2016 - Haziran 2019 tarihleri arasında 5-18 yaş arasında olan ve çarpıntı şikayeti ile çocuk kardiyoloji polikliniğine başvuran 1680 hasta çalışmaya dahil edildi. Hastaların 714'ü erkek $(\% 42,5)$ ve 966 'sı $(\% 57,5) \mathrm{kız}$ idi. Hastaların elektrokardiyografi (EKG), ekokardiyografi, kardiyovasküler stres test, 24 saat ritim Holter, olay kaydedici ve genetik analiz bilgilerini içeren tüm hastane kayıtları incelendi.

Bulgular: Hastaların yaş ortalaması 13,5 $\pm 3,2$ yıl (minimum/ maksimum: 5-17,8 yıl) idi. Çarpıntı şikayetine 218 hastada göğüs ağrısı, 152 'sinde nefes darlı̆̆ı ve 67 'sinde halsizlik şikayeti eşlik ediyordu. Hastalara ait 726 ritim Holter, 165 olay kaydedici, 104 kardiyovasküler stres test incelendi. Hastaların 306'sinda $(\% 18,2)$ disritmi belirlendi. En sk belirlenen disritmiler supraventriküler ekstrasistol ( $\mathrm{n}=171, \% 55,8)$ ve ventriküler ekstrasistol $(\mathrm{n}=82 \% 26,8)$ idi. Beş hasta ventriküler taşikardi, bir hasta uzun QTC sendromu, bir hasta katekolaminerjik polimorfik ventriküler taşikardi (VT) tanısı aldı. İki hasta aritmojenik sağ ventrikül displasizi açısından izleme alındı. Hastaların 12'sinde mitral kapak prolapsusu, 8'inde akut romatizmal ateşe bağlı kalp kapak hastalığı ve 7'sinde biküspit aortik kapak belirlendi.

Sonuç: Çocuklarda yaygın poliklinik başvuru sebeplerinden olan çarpıntı şikayeti sıklıkla iyi huylu patolojilerle ilişkili olsa da ciddi

Address for Correspondence: Kahraman YAKUT, Bezmialem Vakıf University Faculty of Medicine, Department of Pediatric Cardiology, İstanbul, Türkiye

E-mail: kahramanyakut@gmail.com ORCID ID: orcid.org/0000-0002-9221-5636

Received: 08.08.2019

Accepted: 15.10 .2019

Cite this article as: Yakut K. Management and Outcomes of Paediatric Patients with Palpitations Examined in Our Clinic. Bezmialem Science 2020;8(3):282-8. 
Conclusion: Palpitation is one of the common causes of outpatient clinic visits in children and it may be the first symptom of serious arrhythmias, although it is frequently associated with benign pathologies. Most life-threatening dysrhythmias can be detected by a thorough analysis of the patient using basic cardiological examination methods.

Keywords: Palpitation, electrocardiogram, rhythm holter, symptoms, child aritmilerin ilk semptomu olabileceği mutlaka akla getirilmelidir. Hayatı tehdit edebilecek çoğu ritim bozukluklarını hastaların iyi bir şekilde analiz edilmesi ve temel kardiyolojik inceleme metodlarının kullanılması ile saptamak mümkündür.

Anahtar Sözcükler: Çarpıntı, elektrokardiyografi, ritim holter, semptomlar, çocuk

\section{Introduction}

Palpitation is a challenging symptom that is often encountered by paediatric cardiologists. The challenging factors include the pathological findings frequently occurring with the symptoms and symptoms disappearing in most patients during hospital visits. Basal electrocardiography (ECG) rarely provides clues regarding the pathology, usually showing normal findings. Normal findings observed in the first evaluation should not mislead the physician, who should carefully run further tests considering that the patient may be experiencing a rhythm disorder. This study describes the characteristics of patients who presented with palpitation at our clinic, rhythm disorders that were detected, and the treatment methods.

\section{Methods}

Children aged 5-18 years who presented to the paediatric cardiology clinic with complaints of palpitation were included in this study. ECG and echocardiographic examination were performed for all patients. Cardiovascular stress test, 24-h Holter monitoring, event recorder monitoring, cardiac magnetic resonance imaging (MRI) and genetic analyses were performed when necessary. In this study, 726 Holter monitoring, 165 event recorder monitoring, and 104 cardiovascular stress test recordings were evaluated. Patients with complex congenital heart disease were excluded from this study. In addition, patients who did not regularly attend follow-up visits were excluded from the study.

\section{Statistical Analysis}

Statistical analysis was performed using the PASW version 17.0 software (SPSS Inc., Chicago, IL, USA). Descriptive statistics were expressed in mean \pm standard deviation (SD), median (minimum-maximum), or number and frequency. Chi-square test was used to compare the categorical variables. A p value $<0.05$ was considered statistically significant.

\section{Results}

The mean age of the children included in the study was $13.5 \pm 3.2$ years (range: 5-17.8 years). Palpitation was accompanied with chest pain in 218 patients, shortness of breath in 152 patients, weakness in 67 patients, numbness of the hands and face in 21 patients, nausea in 16 patients, dizziness in 12 patients and fainting in three patients. Dysrhythmia was detected in 306 patients (18.2\%). Of the patients with dysrhythmia, 171 $(55.8 \%)$ had supraventricular extrasystole (SVE), 82 (26.8\%) had ventricular extrasystole (VES), 22 (7.2\%) had ectopic atrial rhythm, 12 (4\%) had Wolff-Parkinson-White syndrome (WPW), $9(3 \%)$ had supraventricular tachycardia (SVT), five (1.6\%) had VT episodes, one had long QTc syndrome, one had hyperthyroidism-induced sinus tachycardia, one had atrial flutter (AF), one had focal atrial tachycardia (FAT) and one had catecholaminergic polymorphic VT. Genetic testing was performed in four patients to evaluate their genetic dysrhythmia. Two patients with suspected arrhythmogenic right ventricular dysplasia (ARVD) (Figure 1) were evaluated using cardiac MRI. Of the patients with SVE, 82 (48\%) were male and 89 (52\%) were female. Of the patients with premature VES, 39 (47.6\%) were male and $43(52.4 \%)$ were female. Although no statistically significant difference was noted, the incidence of SVE and VES in males was slightly higher than in females $(\mathrm{p}>0.05)$. Supraventricular extrasystoles identified on Holter monitoring or ECG were considered to be benign dysrhythmias and were followed-up without any treatment. Similarly, 22 patients with ectopic atrial rhythms did not require any treatment. Medical treatment was commenced in 13 of the 82 patients with ventricular extrasystole due to frequent VESs (Figure 2). The

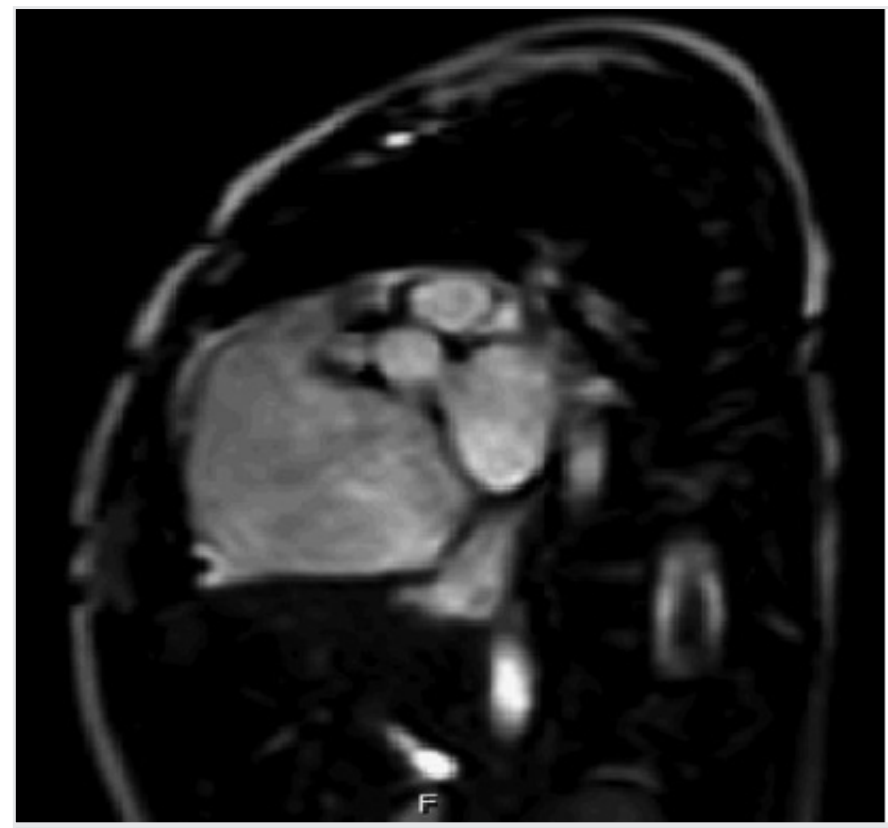

Figure 1. Magnetic resonance imaging of a 3-year-old patient with suspected ARVD shows enlargement of right ventricular outflow tract

ARVD: Arrhythmogenic right ventricular dysplasia 
follow-up Holter monitor recordings performed in all but two of the treated patients showed a significant reduction in VES frequency.

We found that the VES rates were reduced after rearranging the medical treatment in two patients whose first-line treatments were unsuccessful. Sixty-nine patients who were found to have a low VES frequency in the Holter monitoring and who had no increase in VES in the cardiovascular stress test, were considered to have a low risk and followed-up without treatment. Electrophysiological studies (EPS) and catheter ablation were not required in any of the patients with VES. Of the five patients with non-sustained VT episodes, one is currently being followed-up with medical treatment. The remaining four patients who were found to have a short coupling interval and frequent VES were referred to undergo risk analysis for EPS and catheter ablation.

Seven out of twelve patients who were found to have WPW syndrome on ECG were referred for EPS and catheter ablation risk analysis (Figure 3). The other five patients with WPW were younger and had no documented episodes of SVT. Therefore, these patients were placed under clinical follow-up after their families were informed and educated about SVT episodes. Eight of the nine patients with supraventricular tachycardia were referred for catheter ablation. One patient with a slow-fast SVT episode of 10-15 beats in the Holter monitoring was placed under follow-up with medical treatment due to the young age. One patient with hyperthyroidism-induced sinus tachycardia was put on beta-blocker therapy until the results of the thyroid function tests returned to normal. In this patient, sinus tachycardia resolved after the patient's thyroid functions improved. In one patient, FAT was controlled with medical treatment at the acute stage and tachycardia did not recur during the follow-up period. In a patient with a history of exercise-induced syncope, an episode of bidirectional VT developed during the cardiac stress test (Figure 4) and the patient was diagnosed with catecholaminergic polymorphic VT. The patient's symptoms improved after receiving therapy a beta-blocker therapy. Flecainide was also initiated and left sympathetic denervation was performed. One patient diagnosed with long QTc (QTc: $480 \mathrm{msec})$ syndrome was placed under beta-blocker therapy and followed-up. Another

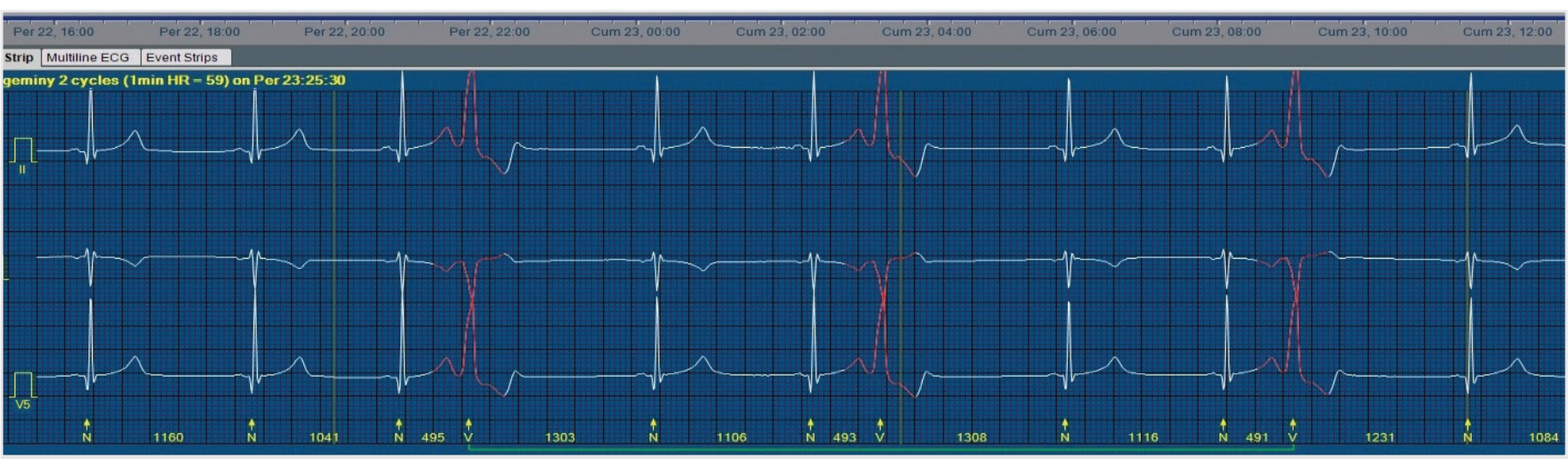

Figure 2. Three-channel 24-h Holter monitoring shows monomorphic VES in a 15-year-old patient VES: Ventricular extrasystole

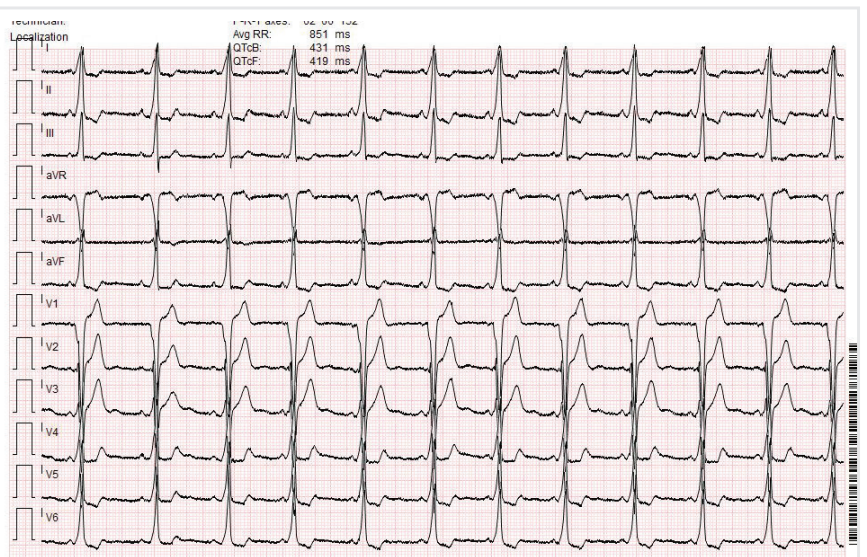

Figure 3. The basal ECG of a 10-year-old patient diagnosed with Wolff-Parkinson-White syndrome who underwent catheter ablation shows a short PR interval, delta wave, and wide QRS

ECG: Electrocardiography

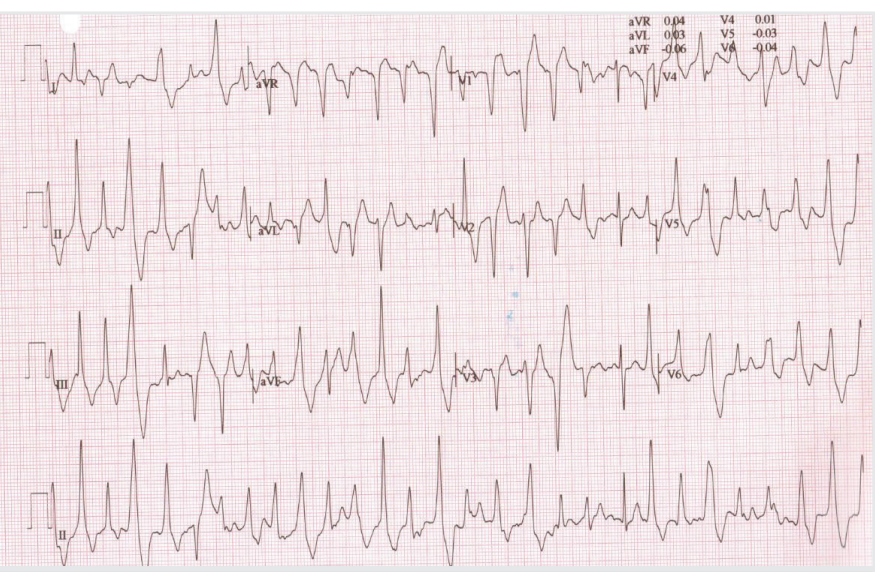

Figure 4. A patient with a history of exercise-induced syncope who had a bidirectional VT episode at the fifth minute of the cardiac stress test was diagnosed with catecholaminergic polymorphic VT

VT: Ventricular tachycardia 
patient diagnosed with atrial flutter started receiving therapy with sodium warfarin (with an INR range of 2-3) and a betablocker to control the heart rate. Sodium warfarin therapy was continued for three weeks and then synchronised cardioversion followed by transoesophageal echocardiography was performed. One month after the cardioversion, the atrial flutter recurred and the patient was referred for catheter ablation therapy.

In addition, MVP was detected in 12, ARF-induced heart valve disease in 8 and BAV in 7 patients included in this study (Table 1). Clinical follow-up of all the patients was continued periodically.

\section{Discussion}

Palpitation is defined as a disturbing sensation of flutter in the chest. Patients may often describe sinus tachycardia when they present with complaints of palpitation. Conditions such as panic disorders, anaemia, hyperthyroidism, obesity and

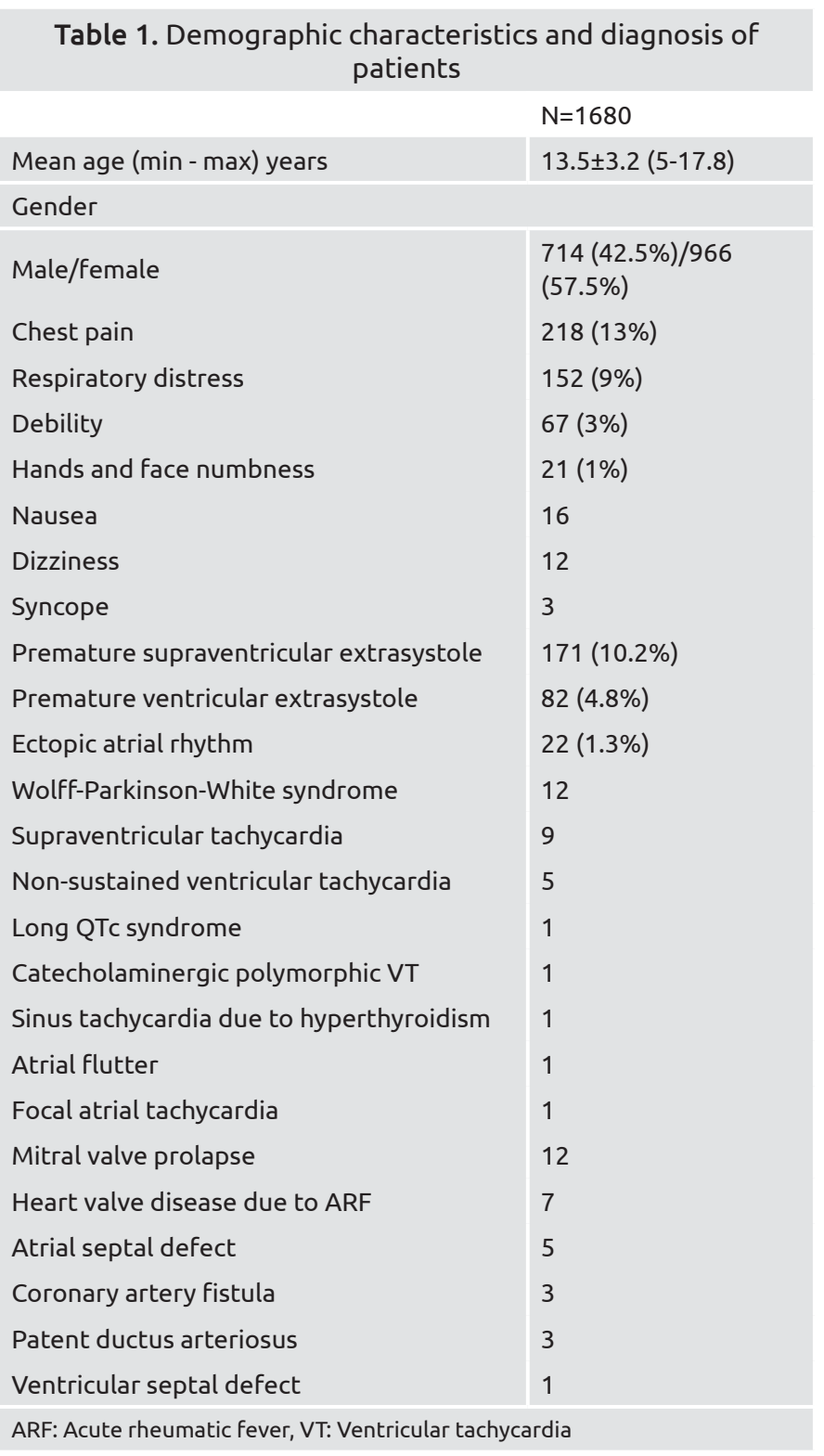

non-cardiac sinus tachycardia such as postural orthostatic tachycardia syndrome may also lead to the complaint of palpitation. Dysrhythmias other than these are also important causes of palpitation. Palpitation is a feeling of discomfort caused by dysrhythmias. The present study primarily focused on dysrhythmias. Patients may express their feeling of palpitation in several ways: by saying that sometimes their heart beats quickly, sometimes there is a feeling of fluttering wings in their chest, sometimes there is a short-term twisting sensation in their chest that repeats from time to time and sometimes it feels as if they felt their heartbeat in their mouth. A detailed history should be obtained before assessing the possibility of dysrhythmia and the need for further examination in a child presenting with a complaint of palpitation. It should be kept in mind that young children may find it difficult to express their feeling of palpitations and it should be known that the underlying causes of fainting and chest pain in paediatric patients may be serious dysrhythmias. Similar to our study, complaints such as chest pain, shortness of breath and fatigue are frequently reported in addition to palpitations (1). SVE and ectopic atrial rhythm are frequently observed in children using 24-h Holter monitoring, although they rarely present with symptoms. They are usually of no clinical significance and do not require treatment (1). The clinical significance of supraventricular extrasystoles is that they can trigger some re-entrant tachycardias. In our study, SVE was the most common dysrhythmia and no patient with SVE required treatment. The nature of the palpitation, its onset and whether or not it is sustained can give us a clue about the cause of the palpitation. One of our patients reported experiencing palpitations for 15 days and that this complaint has been persisting. The patient's ECG showed sinus tachycardia that was incompatible with symptoms and hyperthyroidism was detected in the patient's thyroid function tests. Beta-blocker therapy was commenced for tachycardia and tachycardia resolved after controlling hyperthyroidism.

Nodal premature beats are narrow QRS complexes with no $\mathrm{P}$ wave as the excitation originates from the AV node. Rarely, there may be an inverse $\mathrm{P}$ wave just in front of or behind the narrow QRS complexes. Nodal premature beats are mostly benign and do not require treatment.

The duration of the palpitation with other accompanying symptoms such as fainting and the patient's age facilitates the identification of the underlying cause. Premature VESs are described as occasional twisting and short-term compression in the chest or short-term shortness of breath. When a thorough history is taken, it may be possible to obtain this information from the paediatric patients. Premature VES is common in healthy children as well as in children with heart disease. Without significant heart disease, isolated premature VESs occur in 10$15 \%$ of infants and $20-35 \%$ of adolescents, whereas ventricular tachycardias are rare $(2-5 \%)$. Most are benign and few require treatment (6-8). Consistent with the literature, medical therapy with good response was initiated in very few patients in the present study and none of the patients required EPS and catheter ablation. 
Although ventricular extrasystoles are often idiopathic, they may be associated with cardiomyopathy, myocarditis, diffuse myocardial damage, coronary artery pathologies, hypokalaemia, hypocalcaemia, acidosis, or hypoxemia $(9,10)$. Most of the premature VESs that require medical therapy can be suppressed using drug therapy and catheter ablation may rarely be needed (10). Medical treatment alone was sufficient without the need for catheter ablation in all of our patients with premature VES. A VES rate higher than $20 \%$ of the 24 -h total QRS complex is described as very frequent VES and because this is considered a risk factor for cardiomyopathy, it is recommended that patients be placed on medical therapy or undergo catheter ablation $(8,11-13)$. As reported in the literature, four of our patients with frequent VES who experienced episodes of non-sustained VT were referred for catheter ablation and the VT episodes of one patient were controlled with medical treatment.

The treatment of WPW syndrome depends on the type of dysrhythmia, clinical condition and age of the child. Catheter ablation is the recommended treatment for older children (1418). Catheter ablation has a high success rate and the long-term use of medications is not required (14-18). In our study, in accordance with the recommendations in the literature, older children with WPW syndrome were referred for EPS and catheter ablation. Families of younger patients who had no documented episodes of SVT were taught on how to check the pulse in order to recognise an SVT episode and the patients were placed under clinical follow-up.

The risk of recurrence of SVT in infants is high in the short term; thus, prophylactic antiarrhythmic drug use is required. Prophylactic drugs are usually given for 6-12 months and most infants do not experience recurrence after this period $(19,20)$. The persistence of pre-excitation findings on ECG significantly increases the risk of SVT recurrence. If SVT occurs or persists in older children, catheter ablation is recommended since spontaneous recovery is unlikely (19-22). In the case of SVTs that are resistant to medical therapy, catheter ablation can be performed with high success and low complication rates at any age including new born infants (21-29). In our study, all but one patient with SVT were referred for catheter ablation. One young patient with SVT was followed-up with medical therapy.

Although catecholaminergic polymorphic VT is rare in children, it is one of the dangerous ventricular dysrhythmias with a high mortality risk $(30,31)$. The observation of bidirectional ventricular premature beats and/or polymorphic VT episodes in ECG recordings during exercise or during Holter monitoring are characteristic findings for diagnosis (30,31). Similarly, bidirectional VT episodes were detected in one patient with exercise-induced syncope during the cardiac stress test in our study. In this patient, syncope attacks were not observed after the initiation of beta-blocker plus flecainide therapy together with left cardiac sympathetic denervation.

Arrhythmogenic right ventricular dysplasia is a disease characterised by the replacement of the myocardium of both ventricles, usually the right ventricle by fat and fibrous tissues
$(32,33)$. It occurs in a wide clinical spectrum and the patients may be asymptomatic; however, heart failure, dysrhythmia, or sudden death may be the first sign of the disease $(32,33)$. It is a genetic disease and early diagnosis and treatment increases the quality of life and duration. There is no standalone diagnostic tool for ARVD. Diagnosis is made by clinical, electrocardiographic and radiological features. According to the diagnostic criteria updated in 2010, two major or one major and two minor criteria are required for the definitive diagnosis (33). The two patients in our study did not fully meet the diagnostic criteria but were followed-up as suspicious cases.

The main concerns in patients examined for palpitations are the identification of patients who are at risk of sudden cardiac death and making efforts to reduce this risk; this is a crucial reason for the diagnosis and treatment of dysrhythmias that trigger cardiomyopathies. In our study, a patient with catecholaminergic polymorphic VT and another patient with long QTc syndrome at risk of sudden cardiac death were placed on a therapy. In addition, one patient with AF, one with FAT and patients with frequent polymorphic VES who were considered to be at risk for cardiomyopathy were placed on a therapy.

\section{Study Limitations}

The retrospective design of this study is an important disadvantage with regard to data collection and analysis. The retrospective study design also complicates the testing of the accuracy of diagnosis by questioning the palpitation complaints. The large sample size screened in this study is considered to be an important strength.

\section{Conclusion}

Palpitation is the most important symptom of dysrhythmias in children. In patients presenting with palpitations, the possibility of a cardiac disease that can be fatal and result in sudden death should not be overlooked. Reducing the families' anxiety can only be possible by determining the causes of the palpitations. The most important step for starting treatment is to first detect these dysrhythmias.

\section{Ethics}

Ethics Committee Approval: Retrospective study.

Informed Consent: Retrospective study.

Peer-review: Externally peer reviewed.

Financial Disclosure: The author declared that this study received no financial support.

\section{References}

1. Kang KT, Etheridge SP, Kantoch MJ, Tisma-Dupanovic S, Bradley DJ, Balaji S, et al. Current management of focal atrial tachycardia in children: a multicenter experience. Circ Arrhythm Electrophysiol 2014;7:664-70.

2. Dickinson DF, Scott O. Ambulatory electrocardiographic monitoring in 100 healthy teen age boys. Br Heart J 1984;51:179-83. 
3. Nagashima M, Matsushima M, Ogawa A, Ohsuga A, Kaneko T, Yazaki T, et al. Cardiac arrhythmias in healthy children revealed by 24-hour ambulatory ECG monitoring. Pediatr Cardiol 1987;8:1038.

4. Scott O, Williams GJ, Fiddler GI. Results of 24 hour ambulatory monitoring of electrocardiogram in 131 healthy boys aged 10 to 13 years. Br HeartJ 1980;44:304-8.

5. Southall DP, Richards J, Hardwick RA, Shinebourne EA, Gibbens GL, Thelwall-Jones H, et al. Prospective study of fetal heart rate and rhythm patterns. Arch Dis Child 1980;55:506-11.

6. Conti CR. Ventricular arrhythmias: a general cardiologist's assessment of therapies in 2005. Clin Cardiol 2005;28:314-6.

7. Gaita F, Giustetto C, Di Donna P, Richiardi E, Libero L, Brusin $\mathrm{MC}$, et al. Long-term follow-up of right ventricular monomorphic extrasystoles. J Am Coll Cardiol 2001;38:364-70.

8. Spector ZZ, Seslar SP. Premature ventricular contraction-induced cardiomyopathy in children. Cardiol Young 2016;26:711-7.

9. Alexander ME, Berul CI. Ventricular arrhythmias: when to worry. Pediatr Cardiol 2000;21:532-41.

10. Crosson JE, Callans DJ, Bradley DJ, Dubin A, Epstein M, Etheridge $S$, et al. PACES/HRS expert consensus statement on the evaluation and management of ventricular arrhythmias in the child with a structurally normal heart. Heart Rhythm 2014;11:55-78.

11. Wijnmaalen AP, Delgado V, Schalij MJ, van Huls van Taxis CF, Holman ER, Bax JJ, et al. Beneficial effects of catheter ablation on left ventricular and right ventricular function in patients with frequent premature ventricular contractions and preserved ejection fraction. Heart 2010;96:1275-80.

12. Baman TS, Lange DC, Ilg KJ, Gupta SK, Liu TY, Alguire C, et al. Relationship between burden of premature ventricular complexes and left ventricular function. Heart Rhythm 2010;7:865-9.

13. Takemoto M, Yoshimura H, Ohba Y, Matsumoto Y, Yamamoto $\mathrm{U}$, Mohri M, et al. Radiofrequency catheter ablation of premature ventricular complexes from right ventricular outflow tract improves left ventricular dilation and clinical status in patients without structural heart disease. J Am Coll Cardiol 2005;45:1259-65.

14. Kuck KH, Schlüter M, Geiger M, Siebels J, Duckeck W. Radiofrequency current catheter ablation of accessory atrioventricular pathways. Lancet 1991;337:1557-61.

15. Jackman WM, Wang XZ, Friday KJ, Roman CA, Moulton KP, Beckman KJ, et al. Catheter ablation of accessory atrioventricular pathways (Wolff-Parkinson-White syndrome) by radiofrequency current. N Engl J Med 1991;324:1605-11.

16. Calkins H, Sousa J, el-Atassi R, Rosenheck S, de Buitleir M, Kou WH, et al. Diagnosis and cure of the Wolff-Parkinson-White syndrome or paroxysmal supraventricular tachycardias during a single electrophysiologic test. N Engl J Med 1991;324:1612-8.

17. Calkins H, Yong P, Miller JM, Olshansky B, Carlson M, Saul JP, et al. Catheter ablation of accessory pathways, atrioventricular nodal reentrant tachycardia, and the atrioventricular junction: final results of a prospective, multicenter clinical trial. The Atakr Multicenter Investigators Group. Circulation 1999;99:262-70.
18. Hindricks G. The Multicentre European Radiofrequency Survey (MERFS): complications of radiofrequency catheter ablation of arrhythmias. The Multicentre European Radiofrequency Survey (MERFS) investigators of the Working Group on Arrhythmias of the European Society of Cardiology. Eur Heart J 1993;14:1644-53.

19. Jaeggi E, Öhman A. Fetal and Neonatal Arrhythmias. Clin Perinatol 2016;43:99-112.

20. Etheridge SP, Escudero CA, Blaufox AD, Law IH, Dechert-Crooks BE, Stephenson EA, et al. Life-Threatening Event Risk in Children With Wolff-Parkinson-White Syndrome: A Multicenter International Study. JACC Clin Electrophysiol 2018;4:433-44.

21. Koca S, Akdeniz C, Tuzcu V. Catheter ablation for supraventricular tachycardia in children $\leq 20 \mathrm{~kg}$ using an electroanatomical system. J Interv Card Electrophysiol 2019;55:99-104.

22. Kugler JD, Danford DA, Houston KA, Felix G; Pediatric Radiofrequency Ablation Registry of the Pediatric Radiofrequency Ablation Registry of the Pediatric Electrophysiology Society. Pediatric radiofrequency catheter ablation registry success, fluoroscopy time, and complication rate for supraventricular tachycardia: comparison of early and recent eras. J Cardiovasc Electrophysiol 2002;13:336-41.

23. Van Hare GF, Javitz H, Carmelli D, Saul JP, Tanel RE, Fischbach PS, et al. Prospective assessment after pediatric cardiac ablation: demographics, medical profiles, and initial outcomes. J Cardiovasc Electrophysiol 2004;15:759-70.

24. Aiyagari R, Saarel EV, Etheridge SP, Bradley DJ, Dick M 2nd, Fischbach PS. Radiofrequency ablation for supraventricular tachycardia in children $<$ or $=15 \mathrm{~kg}$ is safe and effective. Pediatr Cardiol 2005;26:622-6.

25. Chiu SN, Lu CW, Chang CW, Chang CC, Lin MT, Lin JL, et al. Radiofrequency catheter ablation of supraventricular tachycardia in infants and toddlers. Circ J 2009;73:1717-21.

26. Akdeniz C, Ergul Y, Kiplapinar N, Tuzcu V. Catheter ablation of drug resistant supraventricular tachycardia in neonates and infants. Cardiol J 2013;20:241-6.

27. Gartenberg AJ, Pass RH, Ceresnak S, Nappo L, Janson CM. Incidence of Echocardiographic Abnormalities Following Pediatric SVT Ablation: Comparison of Cases Utilizing Fluoroscopy Aloneto Caseswith Adjunctive 3D Electroanatomic Mapping. Pediatr Cardiol 2019;40:497-503.

28. Van Hare GF, Javitz H, Carmelli D, Saul JP, Tanel RE, Fischbach PS, et al. Prospective assessment after pediatric cardiac ablation: recurrence at 1 year after initially successful ablation of supraventricular tachycardia. Heart Rhythm 2004;1:188-96.

29. Philip Saul J, Kanter RJ; WRITING COMMITTEE, Abrams D, Asirvatham S, Bar-Cohen Y, Blaufox AD, et al. PACES/HRS expert consensus statement on the use of catheter ablation in children and patients with congenital heart disease: Developed in partnership with the Pediatric and Congenital Electrophysiology Society (PACES) and the Heart Rhythm Society (HRS). Endorsed by the governing bodies of PACES, HRS, the American Academy of Pediatrics (AAP), the American Heart Association (AHA), and the Association for European Pediatric and Congenital Cardiology (AEPC). Heart Rhythm 2016;13:251-89. 
30. Roston TM, Cunningham TC, Sanatani S. Advances in the diagnosis and treatment of catecholaminergic polymorphic ventricular tachycardia. Cardiol Young 2017;27:49-56.

31. Napolitano C, PrioriSG. Diagnosis and treatment of catecholaminergic polymorphic ventricular tachycardia. Heart Rhythm 2007;4:675-8.

32. Brugada J, Blom N, Sarquella-Brugada G, Blomstrom-Lundqvist C, Deanfield J, Janousek J, et al. Pharmacological and non- pharmacological therapy for arrhythmias in the pediatric population: EHRA and AEPC Arrhythmia Working Group joint consensus statement. Europace 2013;15:1337-82.

33. Marcus FI, McKenna WJ, Sherrill D, Basso C, Bauce B, Bluemke DA, et al. Diagnosis of arrhythmogenic right ventricular cardiomyopathy/ dysplasia: proposed modification of the Task Force Criteria. Eur Heart J 2010;31:806-14. 